JCH (Jurnal Cendekia Hukum)

Volume 7 Nomor 1, September 2021

e-ISSN: 2580-1678 dan ISSN: 2355-4657

Open Access: http://e-jurnal.stih-pm.ac.id/index.php/cendekeahukum/index

\title{
NON-PERFORMING LOAN SETTLEMENT FOR RESIDENTIAL PROPERTY DEVELOPERS AMID THE COVID-19 PANDEMIC
}

\section{PENYELESAIAN KREDIT MACET DEVELOPER PROPERTI RESIDENSIAL DITENGAH PANDEMI COVID-19*}

\author{
Lambok Suprianto $^{1}$, Andriyanto Adhi Nugroho ${ }^{2}$ \\ Fakultas Hukum, UPN Veteran Jakarta, DKI Jakarta \\ *e-mail: Lamboksuprianto@upnvj.ac.id ${ }^{1}$ \\ e-mail: Andriyanto.adhi.n@upnvj.ac.id ${ }^{2}$
}

\begin{abstract}
This research discusses the issue of Non-performing loan settlement for residential property developers amid the Covid-19 pandemic. The legal research used is a normative juridical method with a statutory approach. This research was conducted by making an inventory of primary and secondary materials to assess published legal issues. This research examines that the settlement of property developers' bad credit can be done by means of credit rescue and credit settlement. Credit rescue is carried out by providing easy conditions for debtors so that they are expected to complete their credit, which can be done by restructuring credit both inside and outside the court. Meanwhile, credit settlement is carried out by executing the collateral object made by the creditor, such as taking collateral, cessie, subrogation, execution of mortgage rights, lawsuit for default and bankruptcy. In the event of bad credit, creditors will generally choose the bankruptcy route to resolve bad credit by the developer. The bankruptcy of property developers will certainly be very detrimental to property consumers because the position of property consumers is only as concurrent creditors, which means that consumers will get the final payment after preferred creditors and separatists.
\end{abstract}

Keywords: Non-Performing Loan; Non-Performing Loan Settlement; Consumer.

\section{Abstrak}

Penelitian ini membahas isu tentang penyelesaian kredit macet yang dialami oleh developer properti residensial di tengah pandemi covid-19. Penelitian hukum yang digunakan adalah metode yuridis normatif dengan pendekatan perundang-undangan. Penelitian ini dilakukan dengan menginventarisasi bahan primer dan sekunder untuk menilai permasalahan hukum yang dipublikasikan. Penelitian ini mengkaji bahwa penyelesaian kredit macet developer properti dapat dilakukan dengan cara penyelamatan kredit dan penyelesaian kredit. Penyelamatan kredit dilakukan dengan memberikan kemudahan syarat bagi debitur sehingga diharapkan dapat menyelesaikan kreditnya, yang dapat dilakukan dengan cara merestrukturisasi kredit baik di dalam dan diluar pengadilan. Sedangkan penyelesaian kredit dilakukan dengan cara mengeksekusi objek agunan yang dibuat oleh kreditur, seperti pengambilan agunan, cessie, subrogasi, eksekusi hak tanggungan, gugatan wanprestasi dan kepailitan. Dalam hal terjadinya kredit macet, para kreditur umumnya akan memilih jalur kepailitan untuk menyelesaikan kredit macet oleh developer. Pailitnya developer properti tentunya akan sangat merugikan bagi konsumen properti karena kedudukan konsumen properti hanya sebagai kreditur konkuren, yang artinya konsumen akan mendapatkan pembayaran terakhir setelah kreditur preferen dan separatis.

Kata Kunci: Kredit Macet; Penyelesaian Kredit Macet; Konsumen.

\footnotetext{
* Naskah diterima: 23 Januari 2021, direvisi: 7 September 2021, disetujui untuk terbit: 23 September 2021 Doi: $10.3376 /$ jch.v7i1.326
} 


\section{PENDAHULUAN}

Pada pertengahan bulan maret, seluruh dunia digambarkan dengan ditemukannya virus baru yaitu COVID-19 dan digolongkan sebagai pandemi. Hal ini disebabkan karena cara kerja dari virus ini adalah dengan cara mengadakan virus, menghancurkan paru dan melemahkan imun (Fathiyah Isbaniah \& Agus Dwi Susanto, 2020). Penyebaran virus corona yang sangat cepat dan masif, termasuk penyebarannya di Indonesia yang telah menyentuh angka 900 ribu kasus lebih pada akhir tahun 2020. Hal ini mengakibatkan dikeluarkannya Peraturan Pemerintah Nomor 21 Tahun 2020 Tentang Pembatasan Sosial Berskala Besar (PSBB) yang mana meliputi diliburkan tempat sekolah, kerja, kegiatan agama serta pembatasan tempat keramaian. Dampak yang ditimbulkan dari pandemi COVID-19 ini, tidak lagi hanya menyerang pada kesehatan semata akan tetapi telah mengarah pada sistem perekonomian. Dari data yang dikeluarkan oleh Badan Pusat Statistik menjelaskan bahwa setidaknya $84,5 \%$ usaha mikro kecil di Indonesia mengalami penurunan pendapatan dan sebanyak $82,29 \%$ usaha menengah dan besar juga mengalami penurunan pendapatan (Wildan, 2020).

Salah satu bidang usaha yang mengalami dampak dan memegang penting dalam pembangunan ekonomi adalah sektor properti. Sektor properti tercatat mampu menyerap tenaga kerja mencapai 30,34 juta pekerja di seluruh Indonesia. Sektor properti di Indonesia sangat memegang peranan penting dalam pertumbuhan ekonomi di Indonesia, karena pada dasarnya sektor properti adalah multiplier effect dan memegang peranan penting terhadap 174 usaha lainnya. Di tengah pandemi COVID-19 mengakibatkan terjadinya pertumbuhan ekonomi lesu, hal ini dapat dilihat pada penjualan properti residensial pada kuartal ke-III, dimana sektor properti mencatatkan volume penjualan dengan mengalami penurunan sampai dengan $30,93 \%$ secara year on year (yoy). Penurunan terbesar dialami dalam penjualan rumah dengan tipe besar yang mengalami penurunan mencapai $60,03 \%$ dan 24,99\% (CNN, 2020), dan secara triwulan sektor penjualan properti residensial secara keseluruhan mengalami penurunan mencapai 7,8\% ditambah selama pandemi COVID-19 berlangsung tak kurang dari $13 \%$ dari penjualan mengalami pembatalan oleh konsumen. Data ini juga semakin dikuatkan dengan adanya laporan dari Indonesian Property Watch (IPW) yang mencatatkan bahwa penjualan sektor properti di daerah jabodetabek dan banten mengalami penurunan mencapai $31,3 \%$ atau mengalami penurunan dari 2.319 menjadi 1.594 Unit (Klobor, 2020).

Permasalahan yang timbul saat ini bagi para developer properti khususnya sektor residensial adalah mengenai cash flow dari suatu perusahaan. Banyak para developer melakukan efisiensi cost yang mengakibatkan kas yang dimiliki perusahaan digunakan untuk membayar salary (gaji) pekerja dan biaya operasional sehari-hari. Keterbatasan dana 
Lambok Suprianto, Andriyanto Adhi Nugroho: Penyelesaian Kredit Macet Developer...

yang dimiliki oleh developer properti mengakibatkan developer tidak mampu untuk memenuhi kewajiban atau membayar utang mereka kepada kreditur. Hal ini mengingat bahwa saat ini $24 \%$ jumlah kredit yang dimiliki oleh developer adalah kredit jangka pendek sehingga harus dilakukan pembayaran secepatnya. Kondisi keuangan developer properti yang memburuk selama pandemi membuat banyak developer mengalami kredit macet. Dari data yang disampaikan oleh Paulus Totok selaku ketua umum dari organisasi Real Estate Indonesia (REI), mengatakan bahwa lebih dari 50\% developer properti mengalami kredit macet yang mengakibatkan banyak developer meminta untuk melakukan restrukturisasi kredit. Hal ini sejalan dengan tingginya lonjakan kasus Penundaan Kewajiban Pembayaran Utang (PKPU) di pengadilan niaga, dimana pada kuartal II tahun 2020 terdapat 129 Kasus PKPU dan 16 kasus kepailitan, dan pada kuartal III tercatat ada 213 kasus PKPU dan 29 Perkara kepailitan (yulia susanto, 2020). Kurator Imran Nating menyebutkan bahwa sektor yang paling terdampak dan terpukul di tengah pandemi ini adalah sektor properti. Tingginya kasus kredit macet yang dialami oleh developer properti di tengah pandemi seperti ini tentunya akan mengganggu pertumbuhan ekonomi di Indonesia, sehingga oleh dari pada itu harus dicarikan solusi dan penyelesaian kredit macet yang dapat menguntungkan bagi kedua belah pihak.

Di tengah pandemi COVID-19 Penyelesaian kredit macet melalui lembaga pengadilan niaga yaitu dengan Kepailitan dan PKPU mungkin menjadi alternatif yang sangat disukai oleh para kreditur. Hal ini dapat terlihat dari tingginya permohonan Kepailitan dan PKPU di pengadilan niaga. Pailit secara sederhananya adalah suatu kondisi dimana seorang debitur tidak bisa memenuhi prestasinya untuk melunasi kredit atau utangnya kepada para kreditur, yang mana keadaan ini disebabkan karena kondisi kesulitan uang (financial distress) akibat adanya kemunduran dari usaha debitur (Shubhan, n.d.). Keadaan pailit ini dapat dialami oleh siapa saja, baik itu perorangan maupun badan hukum (Ras Ginting, 2018), salah satu contoh developer besar yang mengalami kepailitan di tengah pandemi ini adalah PT. Cowell Development. Dalam hal terjadinya kepailitan developer properti, pihak yang paling dirugikan adalah konsumen. Hal ini dikarenakan dalam hal terjadi kepailitan maka seluruh aset yang dimiliki developer akan disita dan dilelang untuk pembayaran utang, sehingga akan menjadi timbul suatu permasalahan dan pertanyaan bagi konsumen tentang kepastian hukum terhadap properti yang belum melakukan akta jual beli, sehingga hal ini memicu pertanyaan bagi konsumen properti terkait dengan nasib konsumen pasca pailitinya developer.

Berdasarkan latar belakang yang telah diuraikan, maka penulis tertarik untuk mengkaji tentang bagaimana penyelesaian kredit macet developer properti residensial di tengah gelombang pandemi COVID-19 dan bagaimana 
akibat hukum terhadap konsumen properti akibat terjadinya kepailitan terhadap developer.

\section{METODE PENELITIAN}

Dalam penelitian ini penulis menggunakan metode penelitian yuridis normatif, dimana metode penelitian dengan menggunakan sumber kepustakaan sumber kepustakaan sebagai bahan dasar atau data sekunder melalui penelusuran literatur untuk meneliti dan mengkaji permasalahan hukum yang disajikan dalam penelitian ini. Pandangan yuridis normatif menurut Soerjono Soekanto, memberikan pandangan bahwa pendekatan Yuridis normatif sebagai sebuah penelitian hukum yang mengandalkan bahan hukum sekunder atau bahan-bahan kepustakaan yang digunakan sebagai bahan dasar untuk melakukan penelitian, baik dengan cara melakukan penelusuran terhadap peraturan-peraturan maupun literaturliteratur untuk mengkaji permasalahan hukum dalam penelitian (Soekanto \& Mamudji, 2015).

Pendekatan penelitian yang penulis gunakan dalam penelitian ini adalah dengan menggunakan pendekatan perundang-undangan (statute approach), dimana pendekatan ini dilakukan dengan cara mengkaji peraturan perundangundangan yang terkait dengan penelitian ini. Metode pengumpulan data yang dilakukan dalam penelitian ini adalah dengan menggunakan studi kepustakaan (library research), dimana metode ini dilakukan dengan menelaah terhadap literatur-literatur baik berupa bahan hukum primer, bahan hukum sekunder dan bahan tersier.

\section{HASIL DAN PEMBAHASAN}

\section{Penyelesaian Kredit Macet \\ Developer Properti Residensial di} Tengah Pandemi Covid-19.

Penyelesaian kredit macet terhadap developer properti residensial di tengah pandemi covid-19 dapat dilakukan dengan menggunakan dua metode. Metode pertama adalah dengan menggunakan penyelamatan kredit, dan metode yang kedua adalah dengan menggunakan metode penyelesaian kredit. Pada dasarnya keduanya memiliki kesamaan yaitu, untuk menyelesaikan kredit macet yang dialami oleh developer properti, hanya saja ada kelebihan dan kekurangan dalam penyelesaian kredit menggunakan kedua metode tersebut. Adapun penyelesaian kredit macet bagi developer dapat diuraikan sebagai berikut:

\section{a. Penyelamatan Kredit}

Penyelamatan kredit pada dasarnya adalah suatu bentuk penyelesaian kredit macet yang mana dilakukan dengan cara melakukan perundingan kembali antara debitur dan kreditur dimana nantinya akan diberikan beberapa kemudahankemudahan dengan harapan debitur dapat menyelesaikan sisa kreditnya kepada kreditur (Rusmawati, 2015). Penyelamatan kredit cenderung akan menguntungkan kedua belah pihak karena apabila dilakukan dengan itikad baik maka kreditur akan mendapatkan haknya secara penuh, sedangkan untuk debitur juga akan sama menguntungkan karena debitur tetap bisa melanjutkan usahanya sebagaimana mestinya. Penyelamatan 
Lambok Suprianto, Andriyanto Adhi Nugroho: Penyelesaian Kredit Macet Developer...

kredit juga tidak sepenuhnya menguntungkan, karena metode penyelamatan kredit juga bisa menimbulkan ketidakpastian bagi kreditur, apabila setelah diberikan kemudahan syarat bagi debitur namun ternyata debitur tidak mampu memenuhi kewajiban sebagaimana yang telah diperjanjikan.

Penyelamatan kredit pada umumnya lebih dikenal dengan istilah restrukturisasi kredit, dimana di tengah pandemi COVID-19 ini dikenal dengan dua jenis restrukturisasi kredit yang dapat dimanfaatkan oleh debitur untuk menyelamatkan usahanya dari kebangkrutan. Pertama, debitur bisa memilih untuk melakukan restrukturisasi kredit yaitu dengan memanfaatkan stimulus pemerintah dalam Peraturan Otoritas Jasa Keuangan (POJK) No.11/POJK.03/ 2020 dan debitur juga bisa memanfaatkan restrukturisasi kredit melalui pengadilan niaga yaitu dengan mengajukan permohonan Penundaan Kewajiban Pembayaran Utang (PKPU).

\section{1) Restrukturisasi Kredit POJK.No.11/POJK.03/2020}

Dampak yang timbul dari akibat adanya pandemi COVID-19 sudahlah sangat meluas dan bahkan telah merugikan banyak pihak. Menanggapi hal ini, kemudian pemerintah melalui Keputusan Presiden Nomor 12 Tahun 2020 menyatakan bahwa Pandemi COVID-19 merupakan bencana Nonalam, sehingga banyak yang berpendapat bahwa pandemi COVID-19 dapat dikategorikan sebagai force majeure (keadaan memaksa) yang bersifat relatif.
Banyak sektor usaha yang mengalami penurunan pendapatan dan bahkan mengalami kebangkrutan, kemudian pemerintah mengeluarkan stimulus keuangan melalui Peraturan Otoritas Jasa Keuangan Nomor 11/POJK.03/2020, yang ditujukan kepada kredit perbankan. Melalui POJK ini diharapkan dapat memberikan stimulus kebijakan terhadap pelaku usaha yang mengalami dampak akibat pandemi COVID-19 untuk melakukan restrukturisasi kredit kepada pihak perbankan. Restrukturisasi kredit adalah suatu keputusan yang diambil oleh perseorangan atau perusahaan untuk melakukan penataan ulang terhadap kewajiban (utang) kepada kreditur akibat terjadinya kondisi kesulitan ekonomi (Respatia, 2018).

Developer yang mengalami gangguan atas cash flow atau kesulitan keuangan di tengah pandemi COVID-19 dapat mengajukan restrukturisasi kredit kepada kreditur, dalam hal ini adalah pihak perbankan. Developer properti residensial yang mengalami kesulitan keuangan dapat memanfaatkan POJK ini untuk melakukan restrukturisasi kreditnya kepada pihak perbankan dengan batasan utang sebesar 10 Miliar rupiah. Adapun syarat untuk mengajukan restrukturisasi ini adalah:

a) Bahwa debitur (developer) merupakan kredit lancar sebelum pandemi COVID-19 terjadi atau debitur tidak mengalami (default) sebelum COVID-19 terjadi.

b) Bahwa debitur (developer) harus bisa membuktikan bahwa debitur tidak dapat melaksanakan kewajibannya karena usahanya baik secara langsung 
atau tidak langsung berdampak pandemi COVID-19.

Dalam hal developer telah memenuhi syarat diatas, maka developer dapat mengajukan permohonan restrukturisasi kepada pihak perbankan. Kemudian pihak perbankan akan melakukan pemeriksaan, untuk memastikan apakah permohonan restrukturisasi kredit dapat diterima atau tidak. Dalam hal permohonan diterima maka debitur atau developer properti akan diberikan keringanan untuk jangka waktu 1 (satu) tahun. Pemberian restrukturisasi kredit oleh bank kepada debiturnya akan disesuaikan dengan peraturan otoritas jasa keuangan tentang penilaian kualitas asset baik berupa penurunan suku bunga kredit, penambahan jangka waktu kredit, mengurangi angsuran pokok kredit, mengurangi jumlah tunggakan bunga, atau memberikan fasilitas penambahan kredit atau memberikan fasilitas konversi kredit kepada debitur

\section{2) Penundaan Kewajiban \\ Pembayaran Utang (PKPU) di Pengadilan Niaga.}

Penundaan kewajiban pembayaran utang (PKPU) adalah salah satu penyelesaian kredit macet melalui restrukturisasi kredit di dalam pengadilan. PKPU adalah salah satu alternatif dalam pencegahan kepailitan sebab PKPU dapat digunakan oleh debitur yang mengalami kredit macet untuk melakukan renegosiasi kepada kreditur melalui pengadilan niaga, sehingga debitur tetap bisa menjalankan usahanya dengan harapan debitur dapat melunasi kembali kredit di kemudian hari (Harsono et al., 2019). Pada dasarnya
PKPU dilakukan karena adanya alasan atau motivasi hukum sebagai berikut:

a) Sebagai upaya yang dapat dilakukan oleh debitur untuk menyelesaikan kredit macet dan sudah jatuh tempo serta dapat ditagih.

b) Sebagai tangkisan atau pembelaan dari debitur atas adanya permohonan pailit yang dilakukan oleh kreditur.

Selain dari alasan tersebut, PKPU juga dapat dilakukan apabila kreditur melihat dan menilai bahwa debitur yang dapat ditagih tidak mampu membayar kewajibannya, sehingga kreditur dapat memaksa debitur untuk melakukan penundaan kewajiban pembayaran utang di pengadilan niaga. Developer properti yang sedang mengalami kredit macet, dapat mengajukan PKPU kepada pengadilan niaga dengan cara mendaftarkan permohonan kepada pengadilan niaga. Pada saat mengajukan PKPU, developer properti dapat mengajukan rencana perdamaian kepada kreditur dengan harapan rencana perdamaian ini dapat memberikan penyelesaian utang-utang (Huizink, 2004). Penentuan apakah PKPU akan diterima atau tidak tersebut akan digantungkan pada voting atau kesepakatan dari kreditur konkuren dan separatis. Adapun syarat untuk memenangkan PKPU adalah sebagai berikut (Subham, 2008):

(1) Syarat pertama yaitu, Jumlah kreditur konkuren yang hadir harus $1 / 2$ dari jumlah kreditur konkuren, dan sekurang-kurangnya jumlah kreditur konkuren yang hadir harus mewakili lebih dari 2/3 dari jumlah tagihan 
Lambok Suprianto, Andriyanto Adhi Nugroho: Penyelesaian Kredit Macet Developer...

(2) Syarat kedua yang harus dipenuhi adalah bahwa dalam proses PKPU maka debitur harus mendapatkan persetujuan dari kreditur separatis, dimana debitur harus mendapatkan $1 / 2$ dari jumlah kreditur yang piutangnya telah dijaminkan dan harus dihadiri dan dimana kreditur yang hadir tersebut harus memiliki jumlah tagihan hutang paling sedikit $2 / 3$ dari jumlah tagihan kreditur.

\section{b. Penyelesaian Kredit}

Penyelesaian kredit adalah penyelesaian kredit bermasalah dengan cara melalui menjual atau mengeksekusi benda jaminan yang dapat dilakukan dengan meminta bantuan kepada lembaga hukum atau lembaga lainnya. Metode penyelesaian kredit dengan cara mengeksekusi atau menjual benda jaminan tentunya memiliki kelebihan dan kekurangan seperti halnya pada penyelesaian kredit. Keuntungan yang didapatkan khususnya kepada kreditur adalah masalah kepastian hukum, dimana dengan melakukan eksekusi benda jaminan diharapkan dapat memenuhi kewajiban debitur yang bermasalah. Namun hal ini akan menjadi masalah apabila ternyata benda jaminan yang dieksekusi lebih sedikit dibandingkan dengan utang yang dimiliki debitur, sehingga hal ini akan menguntungkan kreditur karena tidak harus melunasi atau memenuhi utang sesuai dengan perjanjian. Namun di sisi lain hal ini akan mengakibatkan debitur tidak dapat menjalankan usahanya sebagaimana biasanya. Penyelesaian kredit dapat ditempuh baik diluar jalur pengadilan (non-litigasi) atau jalur pengadilan (Litigasi). Adapun beberapa penyelesaian kredit macet developer properti yang dapat dilakukan antara lain:

1) Agunan Yang Diambil Alih (AYDA) atau Asset Settlement

Penyelesaian kredit macet bagi developer properti residensial yang dapat dilakukan adalah dengan pengambilalihan agunan (AYDA). Dimana penyelesaian kredit melalui AYDA ini lazim dikenal dalam dunia perbankan. AYDA adalah suatu asset yang dimiliki oleh perbankan, dimana asset tersebut didapatkan dari pelelangan maupun dari luar pelelangan atas dasar kesukarelaan dari pemilik agunan karena terjadinya kredit macet. Penyelesaian melalui AYDA ini cukup disukai oleh perbankan karena prosesnya cepat, sederhana, dan menguntungkan. Dasar hukum dari AYDA diatur dalam Peraturan Bank Indonesia Nomor 14/15/2012 tentang penilaian kualitas asset dan juga diatur dalam pasal 12 Undang-Undang Nomor 10 Tahun 1998 Tentang Perbankan.

Adapun syarat bagi developer properti yang ingin menyelesaikan kredit macet dengan cara AYDA adalah sebagai berikut (Abdilah Surindo Hasibuan, 2020):

a) Developer mengalami kesulitan keuangan atau mengalami kredit macet.

b) Developer kemudian membuat surat pernyataan untuk dilakukan AYDA.

c) Dalam hal disetujui oleh pihak perbankan untuk membeli agunan tersebut dengan harga yang telah dikompensasikan dengan utang. 
d) Pihak perbankan selambat-lambat dalam jangka waktu 1 tahun diwajibkan untuk menjual kembali agunan tersebut.

\section{2) Penjualan Piutang Macet (Cessie)} dan Penggantian Kreditur (Subrogasi)

Penyelesaian kredit macet bagi developer properti juga dapat dilakukan dengan penjualan piutang macet (cessie) oleh debitur. Cessie sendiri telah diatur dalam pasal 613 KUHPerdata, dimana cessie adalah salah satu cara penyelesaian kredit dengan cara mengalihkan tagihan, dan hak-hak yang timbul akibat dari adanya suatu perjanjian yang dapat dilakukan dengan menggunakan akta otentik atau juga bisa menggunakan akta dibawah tangan (Rizky Djangkarang, 2013). Cessie dilakukan dengan maksud dan tujuan agar kreditur mendapatkan pelunasan baik keseluruhan atau sebagian dari kewajiban debitur dari hasil penjualan piutang tersebut kepada pihak ketiga (Marzuki, 2002). Jadi debitur (developer) dan kreditur melalui kesepakatan bersama dapat menjual sebagian atau keseluruhan dari pada utang dimiliki debitur kepada pihak ketiga dengan tujuan bahwa penjualan tersebut dapat melunasi sebagian atau keseluruhan dari utang yang dimiliki oleh debitur.

Selain penjualan jaminan, hal yang dapat dilakukan untuk menyelesaikan kredit macet adalah dengan melakukan subrogasi atau pergantian kreditur. Subrogasi pada dasarnya adalah suatu penyelamatan kredit macet sehingga tidak terjadi eksekusi jaminan oleh kreditur diakibatkan karena terjadinya peralihan kreditur kepada pihak ketiga, dimana pihak ketiga tersebut melakukan pembayaran utang secara keseluruhan sehingga dengan demikian beralih pula hak dan kewajibannya kepada kreditur pihak ketiga (Nopitayuni, 2016). Persyaratan untuk melakukan subrogasi adalah dilakukan dengan mempertimbangkan secara hati-hati, kemudian tidak harus mendapatkan persetujuan dari pada debitur, mempertimbangkan jumlah kredit yang akan dialihkan sama besar dengan kredit, dan apabila dilakukan subrogasi maka agunannya harus dilakukan secara paripasu. (Suyatno, 2018)

\section{3) Eksekusi Hak Tanggungan Melalui}

\section{Pengadilan Negeri}

Penyelesaian kredit macet oleh developer properti yang mengalami kredit macet dapat dilakukan melalui eksekusi hak tanggungan melalui pengadilan negeri. Pada dasarnya eksekusi hak tanggungan dapat dilakukan tanpa melalui pengadilan, namun untuk lebih memberikan kepastian maka kreditur dapat meminta penetapan pengadilan. Dasar hukum dari hak tanggungan telah dituangkan dalam Undang-Undang Nomor 4 Tahun 1996 Tentang Hak Tanggungan. Pada dasarnya hak tanggungan adalah hak-hak yang terdapat diatas tanah yang dapat dijadikan sebagai bentuk jaminan yang dapat digunakan sebagai pelunasan utang dengan memiliki sifat memberikan sifat pendahulu kepada krediturnya (Pratama, 2016). Pada dasarnya eksekusi hak tanggungan dapat dilakukan diluar pengadilan, namun pada kenyataannya sering terjadi 
Lambok Suprianto, Andriyanto Adhi Nugroho: Penyelesaian Kredit Macet Developer...

ketidaksepakatan antara para pihak yang mengakibatkan terkendalanya eksekusi. Untuk memberikan kepastian dan kemudahan bagi kreditur, maka permohonan eksekusi dapat dilakukan melalui pengadilan.

Penyelesaian kredit macet hak tanggungan dapat dilakukan apabila kreditur telah mengalami wanprestasi (kredit macet) dengan cara:

a) Membuat gugatan kemudian mengajukan kepada pengadilan untuk dieksekusi sebagai jaminan pelunasan dari sisa utang.

b) Pada dasarnya eksekusi hak tanggungan dapat dilaksanakan secara langsung tanpa harus meminta kepada pengadilan. Dasar hukum dari eksekusi hak tanggungan terdapat dalam pasal 224 Herzien Inlandsch Reglement dan dalam UndangUndang Nomor 4 Tahun 1996 Tentang Hak Tanggungan dimana diketahui bahwa sertifikat hak tanggungan memiliki keistimewaan karena dapat melakukan eksekusi tanpa harus mendapatkan putusan dari pengadilan atau yang disebut dengan kekuatan eksekutorial. Namun dalam hal tidak terjadi kesepakatan diantara para pihak dapat meminta perintah dari pimpinan pengadilan negeri. (Fikri Assegaf \& Tanjah, 2010).

\section{4) Gugatan Wanprestasi Melalui Pengadilan Negeri}

Penyelesaian kredit macet oleh developer selanjutnya dapat diselesaikan dengan cara kreditur mengajukan gugatan wanprestasi atau perbuatan ingkar janji
(Hendri \& Khoiri, 2018) di pengadilan negeri. Gugatan ini dapat diajukan dengan terlebih dahulu melakukan somasi kepada debitur. Wanprestasi dapat diartikan tidak melakukan sesuatu, melakukan sesuatu tapi terlambat, melakukan sesuatu tetapi tidak sesuai dengan apa yang dijanjikan dan melakukan sesuatu tetapi keliru. Dalam gugatan wanprestasi, apabila debitur terbukti telah melakukan wanprestasi maka debitur dapat dimintakan pertanggung jawaban untuk permintaan ganti rugi atas penderitaan yang dialami oleh kreditur sebagai akibat adanya kelalaian oleh dimintai pertanggung jawaban untuk ganti rugi atas penderitaan yang dialami kreditur, pembatalan perjanjian, pemenuhan hak, peralihan resiko dan membayar biaya perkara (Prayogo, 2016).

Dalam hal ini, apabila terjadi kredit macet yang dialami oleh developer properti maka kreditur dapat mengajukan gugatan wanprestasi kepada pengadilan negeri sesuai dengan domisili hukumnya. Dimana dalam gugatan tersebut kreditur dapat mencantumkan petitum berupa pemenuhan hak, pemberian ganti rugi, meminta pembatalan perjanjian dan meminta agar biaya perkara ditanggung oleh pihak debitur. Akan tetapi kelemahan dari penyelesaian kredit melalui gugatan wanprestasi di pengadilan negeri adalah penyelesaian yang memakan waktu yang lama. Sehingga hal ini akan lebih menguntungkan debitur (developer) dari pada kreditur.

\section{5) Kepailitan}

Penyelesaian kredit selanjutnya yang dapat dilakukan oleh developer adalah 
dengan menggunakan atau melalui gugatan kepailitan di pengadilan niaga. Dalam proses kepailitan maka akan terjadi pembayaran utang debitur kepada kreditur melalui sita umum terhadap seluruh kekayaan debitur, yang kemudian pemberesan utang tersebut akan dilakukan oleh seorang kurator (Saputri et al., 2019).

$$
\text { Syarat untuk mengajukan }
$$
permohonan pailit debitur diatur dalam pasal 2 ayat (1) dan pasal 8 ayat (4) Undang-Undang Nomor 37 Tahun 2004 Tentang Kepailitan dan PKPU yang dapat dilakukan kreditur yaitu:

a) Terdapat 2 (dua) kreditor atau lebih.

b) Utang atau kredit yang dimiliki debitur sudah mengalami jatuh tempo.

c) Kredit atau hutang sudah jatuh tempo.

d) Terdapat utang atau kredit yang belum dibayar debitur kepada minimal satu (1) kreditur.

e) Utang tersebut merupakan dapat ditagih.

f) Pembuktiannya harus sederhana.

Penyelesaian kredit melalui kepailitan dapat dilakukan dengan mengajukan permohonan pailit kepada pengadilan niaga. Penyelesaian kredit macet developer properti melalui kepailitan pada dasarnya adalah hal yang paling banyak dilakukan oleh kreditur. Hal ini dikarenakan penyelesaian kredit melalui kepailitan relatif lebih cepat dibandingkan dengan gugatan wanprestasi di pengadilan negeri. Kemudian penyelesaian kredit melalui kepailitan memiliki kepastian hukum yang lebih baik dibandingkan mekanisme penyelesaian melalui penyelesaian kredit lainnya. Seorang debitur yang telah diputus pailit oleh pengadilan maka mulai pukul 00.00 Waktu Indonesia, maka debitur tersebut otomatis akan kehilangan seluruh haknya atas harta kekayaan yang dimiliki. Namun kepastian dan kecepatan dari proses kepailitan juga memiliki kekurangan, dimana dalam perkara kepailitan, apabila diketahui harta kekayaan debitur lebih sedikit dibandingkan dengan utang yang dimiliki kreditur, maka kreditur harus menerima apabila pelunasan utang tidak sesuai dengan jumlah utang yang seharusnya dibayarkan oleh debitur kepada kreditur.

2. Akibat Hukum Atas Kepailitan Developer Properti Residensial Terhadap Konsumen

Penyelesaian kredit macet developer properti diharapkan dapat memberikan win-win solution kepada kedua belah pihak. Pada kenyataannya hal seperti ini tidak selalu terjadi melainkan para pihak cenderung melakukan penyelesaian kredit dengan cara di eksekusi. Salah satu cara yang paling disukai oleh para kreditur dalam menyelesaikan kredit macet adalah dengan cara melakukan gugatan kepailitan di pengadilan niaga. Hal ini dipilih karena prosesnya lebih cepat, lebih mudah dan yang pasti langsung bisa dieksekusi. Kepailitan sebagai suatu sita umum tidak hanya menjangkau kekayaan debitur saat ini akan tetapi juga terhadap harta debitur yang akan datang. Setelah terjadinya kepailitan, maka selanjutnya akan terjadi peralihan pengurusan harta kepailitan milik debitur yang selanjutnya akan diurus oleh seorang kurator ataupun 
Lambok Suprianto, Andriyanto Adhi Nugroho: Penyelesaian Kredit Macet Developer...

Balai Harta Peninggalan (BHP). Dalam pemberesan harta pailit, seorang kurator dituntut untuk tidak memiliki benturan kepentingan karena kurator memiliki peranan penting baik untuk debitur dan kreditur (Kartoningrat, 2018). Tugas utama seorang kurator adalah untuk memastikan setiap krediturnya dapat mendapatkan pelunasan sesuai dengan kedudukan dan bagian dari masingmasing kreditur (H Ondang, 2017).

Dalam hal terjadinya kepailitan terhadap debitur, kedudukan kreditur akan menjadi sangat penting dalam pemberesan utang debitur. Dalam dunia kepailitan ada 3 golongan kreditur yaitu pertama kreditur preferen, yang kedua kreditur konkuren serta yang ketiga adalah kreditur separatis. Kreditur pertama yaitu kreditur preferen, merupakan kreditur yang memiliki kekhususan dibandingkan kreditur lainnya dimana kreditur preferen mempunyai hak untuk mendapatkan prioritas dalam pelunasan utang. Keistimewaan dari kreditur ini adalah kreditur preferen memiliki kedudukan yang lebih dibandingkan kreditur-kreditur lainnya, dimana keistimewaan ini didapatkan atau diberikan oleh undangundang (Imran Eka Saputra, 2020). Kreditur preferen termasuk kedalam golongan secured creditor hal ini disebabkan karena sifat utangnya yang oleh undang-undang diberikan kekhususan untuk dibayarkan lebih dahulu dibandingkan dengan kreditur lainnya. Oleh sebab itu utang yang dimiliki oleh kreditur preferen harus didahulukan dibandingkan kreditur yang lain.
Kreditur yang kedua adalah kreditur separatis, dan kreditur separatis juga memiliki kekhususan dalam undangundang kepailitan. Kreditur ini merupakan kreditur yang memegang jaminan atas utang dari debitur, sehingga kreditur ini memiliki keistimewaan terhadap eksekusi jaminan. Dalam pasal 55 ayat (1) Undang-Undang Nomor 37 Tahun 2004 Tentang Kepailitan dan PKPU dimana kreditur separatis dapat melakukan eksekusi sendiri terhadap benda jaminan yang dimiliki oleh kreditur dan tidak terpengaruh dengan adanya proses kepailitan yang dialami oleh debitur (Baginda, 2020). Jaminan yang dimiliki oleh kreditur separatis ini dapat berupa hak tanggungan, gadai, hipotik, fidusia atau bentuk jaminan lainya (Slamet, 2016).

Kreditur yang terakhir adalah kreditur yang piutangnya tidak dijaminkan oleh hak-hak kebendaan yaitu kreditur konkuren. Hak-hak kebendaan yang tidak dijaminkan yang dimaksud adalah hakhak kebendaan seperti hak tanggungan, jaminan fidusia, gadai, oleh karena itu disebut dengan unsecured creditor. Persentase pembayaran kepada kreditur konkuren harus mengacu dalam pasal 189 ayat (1) Undang-Undang Nomor 37 Tahun 2004 Tentang Kepailitan dan PKPU ini ditentukan dari keputusan hakim pengawasan dengan cara harus memperhatikan nilai harta pailit. Kreditur konkuren akan mendapatkan pembayaran yang bersumber dari sisa hasil penjualan harta debitur setelah dilakukan perhitungan pembayaran kepada kreditur preferen dan kreditur separatis. 
Dalam hal terjadinya kepailitan developer properti residensial, maka status atau kedudukan dari konsumen properti itu sendiri adalah kreditur konkuren. Konsumen properti tergolong kepada kreditur yang tidak memiliki keistimewaan sehingga konsumen properti akan mendapatkan pembayaran pelunasan setelah dikurangi dengan pembayaran kepada kreditur separatis dan kreditur preferen dengan pembagian secara proporsional atau disebut juga dengan prinsip pari passu pro rata parte (Fitrya Primadhany, 2014).

Ketentuan ini dapat didasarkan pada pasal 36 ayat (1) dan Pasal 37 dari Undang-Undang Kepailitan. Dapat dijelaskan dalam kedua pasal tersebut dalam hal developer properti mengalami kepailitan, sehingga pihak-pihak yang memiliki perjanjian dengan yang dipailitkan dapat meminta kejelasan haknya kepada kurator, khusus bagi konsumen properti sebagaimana yang telah ditetapkan dalam pasal 37 UndangUndang Kepailitan yang menyatakan bahwa dalam hal terjadi kepailitan bagi developer khusus terhadap perjanjian terkait dengan penyerahan benda dagangan, maka dapat dilakukan sebelum pernyataan pailit diputus oleh pengadilan, dalam hal belum terjadi penyerahan maka para pihak yang dirugikan dapat mengajukan diri sebagai kreditur konkuren.

Dalam hal terjadi kepailitan pada developer, maka kedudukan konsumen akan dipengaruhi oleh penyerahan benda perjanjian. Hal ini dikarenakan, Ketika terjadinya putusan kepailitan oleh pengadilan niaga kepada developer maka seluruh gugatan yang diajukan kepada pengadilan negeri akan menjadi tidak memiliki kepastian hukum. Sehingga dengan adanya kepailitan maka developer sudah tidak memiliki tanggung jawab untuk memberikan ganti rugi kepada konsumen properti, sebab developer telah kehilangan hak atas hartanya dan seluruh harta yang dimiliki oleh developer akan masuk kedalam harta budel pailit dan akan dibagikan sesuai dengan golongan krediturnya.

Secara yuridis hubungan developer properti dan konsumen adalah penjual dan pembeli. Jual beli terhadap benda tidak bergerak baru dikatakan terjadi setelah adanya pelunasan dan penyerahan benda tersebut dari penjual kepada pembeli. Proses transaksi jual beli properti pada awalnya dilakukan dengan perjanjian pemesanan. Adanya perjanjian digunakan sebagai bukti untuk memberikan Batasanbatasan kewajiban antara debitur dan kreditur (Nikmah et al., 2020). kemudian setelah perjanjian pemesanan dilakukan maka selanjutnya dapat dilakukan dengan pengikatan perjanjian jual beli atau yang sering disebut dengan PPJB. Setelah perjanjian PPJB dilakukan dan pembangunan properti sudah dilakukan properti dan telah mencapai pembangunan mencapai $20 \%$ maka selanjutnya dapat dilakukan perjanjian akta jual beli atau sering disebut dengan AJB (Nurwulan, 2015). Sehingga konsumen yang sudah melakukan Akta Jual Beli, maka konsumen tersebut tidak perlu khawatir dengan kepailitan dari developer properti 
Lambok Suprianto, Andriyanto Adhi Nugroho: Penyelesaian Kredit Macet Developer...

karena unit yang telah dibeli tersebut tidak lagi menjadi bagian dari harta pailit.

Terhadap konsumen yang belum melakukan akta jual beli (AJB) atas properti yang telah dibeli ataupun yang sudah diangsur pembayarannya sampai dengan putusan pailit oleh pengadilan, maka kedudukan konsumen properti akan menjadi kreditur konkuren sebagaimana yang telah dijelaskan dalam pasal 37 Undang-Undang Kepailitan. Hal ini tentu sangat merugikan konsumen atas pailitnya developer karena kepastian hukum untuk mendapatkan haknya sangatlah tidak jelas. Dalam hal kekayaan debitur lebih kecil dari utang yang dimiliki maka jelas hal ini sangat merugikan konsumen karena kemungkinan besar konsumen tidak mendapatkan apa-apa. Sehingga terhadap konsumen properti yang saat ini sudah memenuhi syarat untuk melakukan akta jual beli maka harus secepat mungkin untuk dilakukan untuk memberikan jaminan kepastian hukum atas properti yang telah dibeli. Dalam hal konsumen telah melakukan akta jual beli dengan developer sebelum adanya kepailitan oleh developer maka kedudukan konsumen bukan lagi menjadi kreditur konkuren dan asset yang telah dibeli tersebut juga tidak akan menjadi masuk kedalam harta bundle pailit milik developer.

\section{SIMPULAN}

Penyelesaian kredit macet developer properti dapat dilakukan dengan menggunakan dua metode yaitu, melalui penyelamatan kredit dan penyelesaian kredit. Penyelamatan kredit pada dasarnya dilakukan dengan memberikan kemudahan syarat kepada debitur sehingga debitur diharapkan dapat menyelesaikan hutangnya kepada kreditur. Penyelamatan kredit dapat dilakukan dengan memanfaatkan restrukturisasi kredit dalam Peraturan Otoritas Jasa Keuangan Nomor 11/POJK.03/2020, Penundaan Kewajiban Pembayaran Utang (PKPU) dalam pengadilan niaga. Sedangkan penyelesaian kredit macet adalah penyelesaian kredit macet dengan melakukan eksekusi terhadap benda jaminan dalam rangka untuk menyelesaikan kredit macet. Penyelesaian kredit macet dapat dilakukan dengan cara Agunan yang diambil alih (AYDA), penjualan piutang macet (cessie), pergantian kreditur (subrogasi), eksekusi hak tanggungan, gugatan wanprestasi, dan kepailitan. Pada dasarnya kedua metode tersebut memiliki kelebihan dan kelemahan, namun penyelesaian kredit dengan menggunakan metode penyelamatan kredit akan lebih menguntungkan debitur dan kreditur di tengah pandemi COVID-19 ini.

Akibat hukum dari pailitnya developer properti terhadap konsumen dapat ditentukan dari kedudukan konsumen dalam hal terjadi kepailitan. Dalam hal konsumen telah membayar lunas atau sudah melakukan angsuran pembayaran properti namun belum melakukan akta jual beli (AJB) maka sesuai dengan pasal 36 ayat (1) dan pasal 37 Undang-Undang Kepailitan maka kedudukan konsumen akan menjadi kreditur konkuren. Sehingga properti yang telah dibeli tersebut akan masuk 
kedalam bundel harta pailit yang akan dibagikan kepada setiap kreditur sesuai dengan tingkatnya dan dalam hal harta pailit lebih kecil dari utang developer maka bisa dipastikan konsumen bisa tidak mendapatkan apa-apa dari pailitnya developer.

\section{UCAPAN TERIMAKASIH}

Penulis ingin mengucapkan terimakasih yang sebesar-besarnya kepada:

1. Bapak Andriyan Adhi Nugroho, S.H, M.H selaku dosen pembimbing yang telah membantu penulis dalam menyelesaikan penelitian ini.

2. Kepada kedua Orang Tua dan seluruh keluarga yang telah memberikan bantuan materi dan doa dalam menyelesaikan penelitian ini.

3. Kepada Bapak Marudin Hutahaean dan Ibu Saulina Br. Pangaribuan yang telah memberikan bantuan materi dan doa dalam menyelesaikan penelitian ini

\section{DAFTAR PUSTAKA}

Abdilah Surindo Hasibuan, M. (2020). Pembuatan Kuasa Menjual Dalam Penyelesaian Kredit Macet Oleh Bank Dengan proses Aset Yang Diambil Alih (AYDA). Recital Review, 2(1), 117-127.

Baginda, I. V. (2020). Pelaksanaan Hak Kreditur Separatis Terhadap Harta Debitur Pailit Insolven. Lex Privatum, 8, 1689-1699.

CNN. (2020, November). Survei BI: Kuartal III, Penjualan Hunian Anjlok 30,93 Persen. CNN.News. https://www.cnnindonesia.com/ekon omi/20201112114457-532568925/survei-bi-kuartal-iiipenjualan-hunian-anjlok-3093persen
Fathiyah Isbaniah, \& Agus Dwi Susanto. (2020). Pneumonia Corona Virus Infection Disease-19 (COVID-19). Journal Of The Indonesian Medical Association.

https://doi.org/10.47830/jinmavol.70.4-2020-235

Fikri Assegaf, A., \& Tanjah, E. (2010). Penjelasan Hukum Tentang Grosse Akte. National Legal Reform.

Fitrya Primadhany, E. (2014). Perlindungan Hukum Terhadap Konsumen Perumahan Graha Dewata Akibat Dipailitkanya PT. Dewata Abadi Nusa. Arena Hukum, 7(2), 172-194.

H Ondang, Q. (2017). Tugas Dan Tanggung Jawab Kurator Dalam Pengurusan Dan Pemberesan Harta Pailit Menurut Undang-Undang Nomor 37 Tahun 2004. V(7), 1-9.

Harsono, I., Prananingtyas, P., Studi, P., Kenotariatan, M., Hukum, F., \& Diponegoro, U. (2019). Analisis Terhadap Perdamaian Dalam Pkpu Dan Pembatalan Perdamaian Pada Kasus Kepailitan Pt Njonja Meneer, Jurnal hukum Notarius. 12(2), 10671088.

Hendri, J., \& Khoiri, K. (2018). Tinjauan Yuridis Terhadap Wanprestasi Dalam Hal Hutang Piutang. JCH (Jurnal Cendekia Hukum), 3(2), 116. https://doi.org/10.33760/jch.v3i2.22

Huizink, J. . (2004). Insolventie. Fakultas Hukum Universitas indonesia.

Imran Eka Saputra. (2020). Kedudukan Hukum Kreditor Preferen Pajak dan Kreditor Preferen Buruh dalam Proses Kepailitan. Al-Ishlah : Jurnal Ilmiah Hukum, 23(2), 155-166. https://doi.org/10.33096/aijih.v23i2.4 4

Kartoningrat, R. B. (2018). Mediasi Sebagai Alternatif dalam Pengurusan dan Pemberesan Harta Pailit oleh Kurator Kepailitan Mediation As an Alternative in Managing and Ordering of Bankrupt Treasures by the Bankruptcy 
Lambok Suprianto, Andriyanto Adhi Nugroho: Penyelesaian Kredit Macet Developer...

Curator. 2(1), 291-305.

Klobor, P. (2020). Penjualan Perumahan Kuartal III 2020 Turun. Indonesia Properti Channel. https://propertyandthecity.com/penju alan-perumahan-kuartal-iii-2020turun/

Marzuki, M. (2002). Properti dan Real Estate Muryati Marzuki . Restrukturisasi Kredit Sektor Properti dan Real Estate Prospek InvestasI PropertiPasca RekapitulasI Perbankan . Semarang . Jawa Tengah: Dewan Pimpinan. Jurnal Hukum, 9(19), 64-80.

Nikmah, M., Disemadi, H. S., \& Purwanti, A. (2020). Akibat Hukum Perjanjian Jual Beli Rumah Melalui Kredit Pemilikan Rumah Secara Over Credit Di Bawah Tangan. JCH (Jurnal Cendekia Hukum), 6(1), 13. https://doi.org/10.33760/jch.v6i1.254

Nopitayuni, N. K. (2016). Penyelamatan Benda Jaminan Milik Pihak Ketiga Dalam Hal Debitur Wanprestasi. Portalgaruda.Org, 04(02), 1-5.

Nurwulan, P. (2015). Aspek Hukum Transaksi Jual Beli Rumah Susun/Apartemen Di Daerah Istimewa Yogyakarta Kaitannya Dengan Peran Notaris-Ppat. Jurnal Hukum Ius Quia Iustum, 22(4), 674 697.

https://doi.org/10.20885/iustum.vol2 2.iss 4 .art8

Pratama, W. (2016). Tinjauan Hukum Tentang Sertifikat Hak Tanggungan Menurut Undang-Undang Nomor 4 Tahun 1996. Legal Opinion, 3(6). https://doi.org/10.24843/ac.2020.v05 i01.p07

Prayogo, S. (2016). Penerapan BatasBatas Wanprestasi Dan Perbuatan Melawan Hukum Dalam Perjanjian. III(2), 56.

Ras Ginting, E. (2018). Hukum Kepailitan: Teori Kepailitan,. sinar grafika.

Respatia, W. (2018). Kebijakan Restrukturisasi Utang Melalui Debt
To Equity Swap. EKUITAS (Jurnal Ekonomi Dan Keuangan), 14(1), 8296.

https://doi.org/10.24034/j25485024.y 2010.v14.i1.231

Rizky Djangkarang, M. (2013). Aspek Hukum Pengalihan Hak Tagihan Melalui Cessie. Lex Privatum, I(5), 75-84.

https://ejournal.unsrat.ac.id/index.ph $\mathrm{p} /$ lexprivatum/article/view/3081

Rusmawati, D. E. (2015). Tinjauan Yuridis Penyelamatan Dan Penyelesaian Kredit Macet (Studi Pada Koperasi Kredit Mekar Sai Bandar Lampung). FIAT JUSTISIA:Jurnal Ilmu Hukum, 6(1), $1-8$.

https://doi.org/10.25041/fiatjustisia.v 6no1.349

Saputri, E. M., Waspiah, W., \& Arifin, R. (2019). Perlindungan Hukum Terhadap Konsumen Dalam Hal Pengembang (Developer) Apartemen Dinyatakan Pailit. Jurnal Hukum Bisnis Bonum Commune, 2(2), 151. https://doi.org/10.30996/jhbbc.v2i2.1 936

Shubhan, H. (n.d.). Hukum Kepailitan: Edisi Revisi (4th ed.). kencana.

Slamet, S. R. (2016). Perlindungan Hukum Dan Kedudukan Kreditor. Forum Ilmiah, 13(1). file:///C:/Users/Leonora/Documents/ mey/TUGAS/New folder/kepailitan pertama.pdf\%0D

Soekanto, soerjono, \& Mamudji, S. (2015). Penelitian Hukum Normatif Suatu Tinjauan Singkat. Rajawali Pers.

Subham, H. (2008). Hukum Kepailitan: Prinsip Norma dan Praktik Peradilan. kencana.

Suyatno, A. (2018). Kepastian Hukum Dalam Penyelesaian Kredit Macet: Melalui Eksekusi Jaminan Hak Tanggungan Tanpa Proses Gugatan Di Pengadilan'. Kencana.

Wildan, M. (2020, September). "Survei terbaru BPS: 82,8\% Pelaku Usaha 
Jurnal Cendekia Hukum: Vol. 7, No 1, September 2021

Akui Alami Penurunan Pendapatan.

News

Dttc.

https://news.ddtc.co.id/survei-

terbaru-bps-828-pelaku-usaha-akui-

alami penurunan-pendapatan-

23934?page_y $=769$, diakses pada tanggal 12 November 2020.

Yulia Susanto, V. (2020). Ini penyebab laporan PKPU di tahun 2020 meningkat. Kontan.Co.Id. https://nasional.kontan.co.id/news/ini -penyebab-laporan-pkpu-di-tahun2020-meningkat 